\title{
Ăğın (Elâzı̆̆) çevresinde Alt Miyosen yaşlı kırıntılı ve karbonatlı birimlerden beslenen yeraltı sularının hidrojeokimyasal karakteristikleri
}

\author{
The hydrogeochemical characteristics of groundwaters recharging from the Lower Miocene \\ clastic and carbonate units around Ă̆ın (Elâzı̆̆)
}

Özlem ÖZTEKIN OKAN*1,a, Özgür CANPOLAT ${ }^{2, b}$

${ }^{1}$ Fırat Üniversitesi, Mühendislik Fakültesi, Jeoloji Mühendisliği Bölümü, 23119, Elâzı̆̆g

${ }^{2}$ Fırat Üniversitesi, Su Ürünleri Fakültesi, Su Ürünleri Temel Bilimleri Bölümü, 23119, Elâzı̆̆

• Geliş tarihi / Received: 01.10.2021 • Düzeltilerek geliş tarihi / Received in revised form: 03.12.2021 • Kabul tarihi / Accepted: 12.12 .2021

\section{$\ddot{O} \mathbf{z}$}

$\mathrm{Bu}$ çalışmada, Keban Baraj Gölü beslenme havzası içerisindeki Ağın ilçesi yeraltı sularının hidrojeokimyasal karakteristikleri incelenmiştir. Çalışma kapsamında sulardaki majör anyon, katyon ve bazı potansiyel toksik elementlerin kökenleri ortaya konmuş, sular Türkiye ve Dünya'daki içme suyu standartları ile karşılaştııılmıştır. İncelenen yeraltı suları yağışlı ve kurak dönem olmak üzere iki dönemde örneklenmiştir. Örneklemesi yapılan sular Alibonca Formasyonu'na ait tabakalı kireçtaşlarından beslenmekte olup $\mathrm{Ca}-\mathrm{HCO}_{3}$ ve $\mathrm{Ca}-\mathrm{Mg}-\mathrm{HCO}_{3}$ tipindedir. Suların sıcaklık, $\mathrm{pH}$, EC değerleri ile $\mathrm{Cl}^{-}$ve $\mathrm{SO}_{4}^{-2}$ içeriklerinde dönemsel farklıllklar belirlenmiştir. Su örnekleri genel olarak majör anyon, katyon, $\mathrm{Al}, \mathrm{Cr}, \mathrm{Cu}$, $\mathrm{Fe}, \mathrm{Mn}, \mathrm{Pb}, \mathrm{Zn}$, Ni içerikleri bakımından içme amaçlı kullanıma uygundur. Sahile yakın bir noktada açılmış olan sondaj kuyusunda, yağışlı dönemde, $\mathrm{Al}$ (612.00 ppb), $\mathrm{Fe}$ (569.00 ppb) ve Mn (52.1 ppb) içerikleri içme suyu standartlarının üst sınır değerlerinin üzerinde çıkmakla birlikte $\mathrm{Cu}, \mathrm{Cr}$ ve $\mathrm{Zn}$ içerikleri de diğer sulara göre daha yüksektir. Genel olarak incelenen suların majör anyon, katyon, potansiyel toksik element içeriklerini kontrol eden temel faktörün yeraltı suyukayaç etkileşimi olduğu ortaya konmuştur. Bunun yanında suların hidrojeokimyasal özelliklerinin besi ahırları, tarımsal gübre kullanımı gibi antropojenik faktörlerden de etkilendiği belirlenmiştir. Ayrıca, özellikle yağışlı dönemde sondaj kuyusunda belirlenen yüksek potansiyel toksik element içerikleri, Keban Baraj Gölü'nden tatlı su akiferine doğru bir girişimin olabileceğini düşündürmektedir.

Anahtar kelimeler: Ağın, Hidrojeokimya, Keban Baraj Gölü, Potansiyel toksik element, Yeraltı suyu- kayaç etkileşimi

\begin{abstract}
Ağın district is presented within the recharge basin of Keban Dam Lake. The hydrogeochemical characteristics of groundwaters of Ăğn district were investigated in this study. Within the scope of the study, the origins of major anions, cations, some potentially toxic elements in groundwaters were investigated, and the hydrogeochemical features of groundwaters were compared and evaluated with the drinking water standards in Turkey and the world. The groundwaters were sampled in the rainy and the dry seasons. The aquifer formation of the groundwaters is stratified limestones of Alibonca formation and groundwaters are grouped as Ca-HCO3 and Ca-Mg-HCO3 type waters. Seasonal changes were determined in the temperature, $\mathrm{pH}$, EC values, Cl- and SO4-2 contents of the groundwaters. The groundwaters are generally suitable for drinking purposes in terms of major anion, cation, $\mathrm{Al}, \mathrm{Cr}, \mathrm{Cu}, \mathrm{Fe}, \mathrm{Mn}, \mathrm{Pb}, \mathrm{Zn}$, $\mathrm{Ni}$ contents. However, the groundwater of the borehole drilled close to the Keban Dam lake beach is not suitable for drinking in terms of $\mathrm{Al}$ (612.00 ppb), Fe (569.00 ppb) and Mn (52.1 ppb) concentrations, which are determined above the maximum limit values of drinking water standards during the rainy season. Furthermore, $\mathrm{Cu}, \mathrm{Cr}$ and $\mathrm{Zn}$ concentrations in this borehole' groundwater are higher compare to others during the rainy season. In general, groundwater-rock interaction is the the main factor controlling the major anion, cation, and potentially toxic element contents of the studied groundwaters. In addition, the hydrogeochemical properties of the groundwaters are also affected by anthropogenic factors such as livestock barns and the use of agricultural fertilizers. High concentrations of potentially toxic element contents determined in the borehole, especially during the rainy season, could suggest that there may be lake water intrusion from Keban Dam into the freshwater aquifer.
\end{abstract}

Keywords: Ă̆ın, Hydrogeochemistry, Keban Dam Lake, Potentially toxic element, Groundwater-rock interaction

\footnotetext{
${ }^{*}$ äzlem ÖZTEKIN OKAN; ooztekin@firat.edu.tr, Tel: (0424) 23700 00, orcid.org/0000-0003-2934-2170

${ }^{\mathrm{b}}$ orcid.org/0000-0001-7498-600X
} 


\section{Giriş \\ 1. Introduction}

Son yıllarda Dünya genelinde hizla artan nüfusa paralel olarak su kaynaklarının da içme- kullanım amaçlı tüketimi de artmıștır. Küresel iklim değişikliğinin sonuçlarından biri olan kuraklık en fazla su kaynaklarını etkilemektedir. $\mathrm{Bu}$ değişimine bağlı olarak Türkiye'de yaz aylarında ortalama sıcaklıklarda artış gözlenirken, kış mevsimi ortalama yağıșları azalmıștır (T.C. Orman ve Su İşleri Bakanlığ 1 , 2016). Artan kuraklık ve buna bağlı yaşanan yüzey sularının kaybı su kaynaklarının varlığını doğrudan tehdit etmektedir (Çapar, 2019). Bu nedenle Dünya genelinde olduğu gibi ülkemizde de su kaynaklarının doğru yönetimi, su kaynaklarının kalitesini koruyarak devamlılığını sağlamak oldukça önem kazanmıştır. Mevcuttaki su kaynaklarının içme ve kullanmaya uygunluklarını belirlemek ve su kaynaklarının kalitesinin korunmasına yönelik pek çok hidrojeokimya çalışmaları yapılmıştır (Göçmez vd., 2007; Sipahi \& Uslu, 2016, Tahmasebzadeh Bastam \& Gültekin, 2017; Aksever, 2019; Semiz vd., 2021). Yapılan çalışmalarda kireçtaşı akiferlerinden beslenen sı̆ dolaşımlı yeraltı sularının hidrojeokimyasal evriminin esas olarak karbonatların, jips ve halit minerallerinin çözünmesi/çökeltilmesi ve katyon değişimi gibi faaliyetler tarafından kontrol edildiği belirtilmektedir (Şener \& Güneş, 2015; Abdelshafy vd., 2019; Perez-Ceballos vd., 2021). Yapilan çalışmalarda yüzey ve yeraltı suyu kalitesini bozan temel etkenlerin antropojenik kökenli oldukları, bunun yanı sıra $\mathrm{Mn}, \mathrm{Ni}, \mathrm{Cr}, \mathrm{Fe}, \mathrm{Cu}, \mathrm{Al}$ gibi çeşitli metallerin jeolojik kökenli olduğu belirtilmiştir (Hussien \& Faiyad, 2016; Yuan vd., 2017; Davraz ve Batur, 2021).

Ülkemizin en önemli su kaynaklarından olan ve çalışma alanı içerisinde bulunan Keban Baraj Gölü (Elâzı ̆̆), başlıca kentsel, endüstriyel ve tarımsal nedenlerle olmak üzere ciddi bir kirlenme tehlikesiyle karşı karşıyadır. Bu çalışma ile, Keban Baraj Gölü beslenme havzası içerisinde bulunan, kırıntılı ve karbonatlı kayaçlardan beslenen yeraltı sularının majör ve potansiyel toksik element hidrojeokimyası ile, iyonların kökenleri incelenmiş ve içme amaçlı tüketim açısından çeşitli standartlarla karșılaștırılmıștır. Çalıșma alanı Elâzı ̆ il merkezinin $77 \mathrm{~km}$ kuzeybatısında bulunmaktadır (Şekil 1). İlçenin en önemli gelir kaynağını tarım oluştururken daha az oranda da hayvancilık yapılmaktadır.

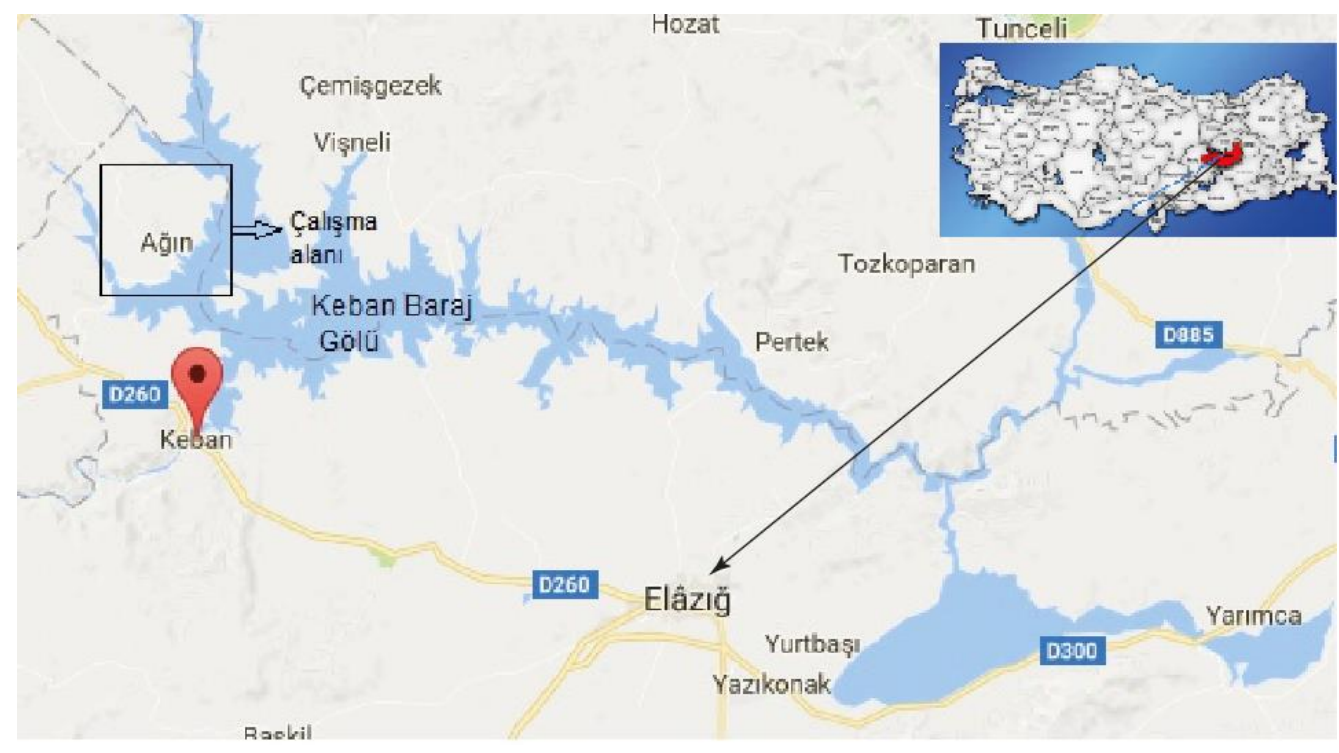

Şekil 1. Çalışma alanının yer bulduru haritası

Figure 1. Location map of study area

\section{Materyal ve yöntem}

2. Material and method

Çalışma kapsamında örneklenen 9 adet su örneğinin koordinatları GPS yardımıyla belirlenmiştir (Tablo 1). Su örneklemeleri yağışlı dönemi temsil eden Mayıs ve kurak dönemi temsil eden Eylül aylarında yapılmıştır. 
Tablo 1. İncelenen yeraltı suyu örnekleme noktalarının koordinat bilgileri

Table 1. Coordinates of groundwater sampling points

\begin{tabular}{lllll}
\hline $\begin{array}{l}\text { Örnek } \\
\text { Numaras1 }\end{array}$ & Örnek noktas1 & X değeri & Y değeri & $\begin{array}{l}\text { Rakım } \\
(\mathrm{m})\end{array}$ \\
\hline AÇ-1 & Çeşme & 4311334 & $37 \mathrm{~S} 472873$ & 708 \\
AÇ-2 & Çeşme & 4311294 & $37 \mathrm{~S} 474615$ & 948 \\
AÇ-3 & Çeşme & 4312698 & $37 \mathrm{~S} 472315$ & 1021 \\
AÇ-4 & Çeşme & 4313650 & $37 \mathrm{~S} 471278$ & 1067 \\
AÇ-5 & Çeşme & 4311069 & $37 \mathrm{~S} 472565$ & 1023 \\
AÇ-6 & Keson kuyu & 4310896 & $37 \mathrm{~S} 472542$ & 1006 \\
AÇ-7 & Çeşme & 4314111 & $37 \mathrm{~S} 476531$ & 1020 \\
AÇ-8 & Çeşme & 4313321 & $37 \mathrm{~S} 477210$ & 950 \\
AÇ-9 & Sondaj kuyusu & 4310288 & $37 \mathrm{~S} 476187$ & 865 \\
\hline
\end{tabular}

Örnekleme esnasında suların sicaklık, pH, elektriksel iletkenlik parametreleri yerinde YSI marka çoklu parametre ölçüm cihazı ile belirlenmiştir. Klorür $\left(\mathrm{Cl}^{-}\right)$, sülfat $\left(\mathrm{SO}_{4}{ }^{-2}\right)$, bikarbonat $\left(\mathrm{HCO}_{3}^{-}\right)$, bileşenlerinin analizi için su örnekleri $500 \mathrm{~mL}$ 'lik polietilen şişelere herhangi bir koruma uygulanmaksızın alınmıştır. Katyon analizi yapılacak örnekler $50 \mathrm{ml}$ 'lik polietilen, sızdırmaz kapaklı şişelere; örnekleme sonrası oluşabilecek reaksiyonların engellenmesi açısından derişik yüksek saflıktaki nitrik asit $\left(\mathrm{HNO}_{3}\right)$ ile $\mathrm{pH}<2$ olacak şekilde eklenerek alınmıştır. Örnekler, analiz sürecine kadar $+4^{\circ} \mathrm{C}$ 'de laboratuvar tipi buzdolabında muhafaza edilmiştir. Suların katyon ve potansiyel toksik element analizleri Kanada'da ACME laboratuvarında ICPMS ile yaptırılmıştır. $\mathrm{Cl}^{-}, \mathrm{SO}_{4}{ }^{-2}, \mathrm{HCO}_{3}{ }^{-}$analizleri Fırat Üniversitesi Jeoloji Mühendisliği Bölümü Hidrojeoloji laboratuvarında Nova 60 Spektroquant ve DR6000 cihazları ile kitler kullanılarak yapılmıştır. Kayaçların $\mathrm{Al}_{2} \mathrm{O}_{3}, \mathrm{Fe}_{2} \mathrm{O}_{3}$, $\mathrm{MnO}$ analizleri ICP-AES ile ACME laboratuvarında (Kanada) yaptırılmıştır. Yapılan arazi ve laboratuvar çalışmaları sonucunda elde edilen değerler büroda sayısal ortama aktarılmıştır. Sayısallaştırma işleminde bölgenin jeoloji haritası çizilirken Adobe Illustrator CS5 program1, kimyasal analiz sonuçlarının değerlendirilmesinde ise AquaCHEM 3.70 programı kullanılmıştır.

\section{Jeoloji ve hidrojeoloji}

3. Geology and hydrogeology

İnceleme alanında yaşlıdan gence doğru PermoTriyas yaşlı Keban Metamorfitleri, Alt Miyosen yaşlı Alibonca Formasyonu, Alt MiyosenPliyosen yaşlı volkanitler ve bunlarla yanal ve düşey geçişli Üst Miyosen- Pliyosen yaşl1 volkanosedimanter özellikte gölsel çökeller yüzeylemektedir (Şekil 2).
Çalışma alanının temelini Keban Metamorfitleri'ne ait kayaçlar oluşturmaktadır. Kipman (1981), Keban Metamorfitleri'ni esas yayılımını gösterdiği Keban çevresinde mermerler, rekristalize kireçtaşı-kalkşist ve metakonglomerakalkfillit olmak üzere üç birime ayırıp incelemiştir. Çalışma alanının kuzeyinde yüzeyleme veren Keban Metamorfitleri, bu bölgede altere olmuş, ağırlıklı olarak beyaz renkli, sert, masif ve karstik boşluklu rekristalize kireçtaşlarından meydana gelir.

Ağın çevresinde geniş yayılım gösteren ve denizel çökellerden oluşan Alibonca Formasyonu, Keban Metamorfitleri'ni açısal uyumsuzlukla örter. Birim genel olarak tabanda kalın tabakalı ve yer yer masif yapılı kireçtaşları ile başlar, üst düzeylerine doğru kumtaşı ara seviyeleri içeren marnlara geçer. Üste doğru tüfit, tüflü marn ardalanmalarından oluşur. Alibonca Formasyonu'nun çökeldiği ortam başlangıçta sı̆̆ ve hareketli bir ortamı simgelemektedir. Bu ortam giderek derin ve sakin bir ortama dönüşmüş ve bu ortamda türbidik akıntılarla kumtaşı-marn ardalanmalı çökeller oluşmuştur (Kürüm vd., 1999).

Ağın kuzey ve batısında yayılım gösteren Alt Miyosen-Pliyosen yaşlı volkanitler ile volkanosedimanter çökelleri Doğu Anadolu Bölgesi’nde geniş yüzeylemeler sunmaktadır. Türkmen ve Aksoy (1998), Arapgir (Malatya), Çemişgezek (Tunceli), Elâzı̆g dolaylarındaki Neojen birimlerinin stratigrafik-sedimantolojik açıdan incelemiş ve bölgesel korelasyonunu tespit etmişlerdir. İnceleme alanında altta tüflerle başlayıp, tüf-çamurtaşı ardalanmasıyla devam eden istif, bazaltik lav akıntıları ve en üstte gölsel çörtlü kireçtaşları ile sona erer.

Çalışma alanında yeraltı suyu taşıyan birimler Keban Metamorfitleri'ne ait rekristalize kireçtaşları, Alt Miyosen yaşlı denizel çökellere ait 
kireçtaşları, Alt Miyosen- Pliyosen yaşlı kireçtaşları ile çatlaklı bazaltlardır (Çetindağ, 2002; Öztekin Okan ve Çetindağ, 2005; Öztekin Okan vd., 2018). Çalışma kapsamında incelenen yeraltı sularının akifer birimleri Alibonca Formasyonu'na ait tabakalı kireçtaşlarıdır. Denizel ve gölsel çökeller içerisinde bulunan marnlı seviyeler geçirimsiz birimleri oluşturmaktadır.

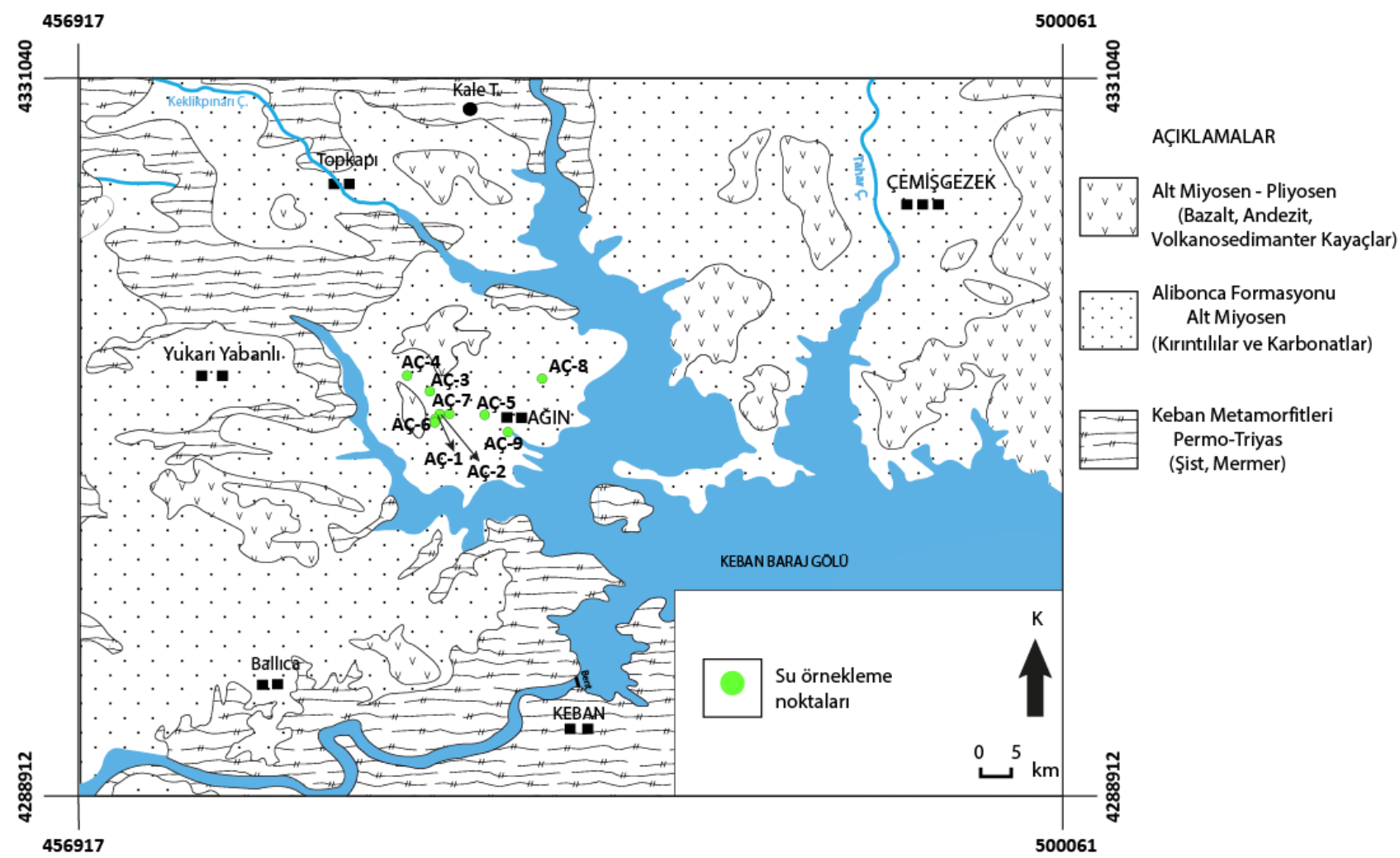

Şekil 2. İnceleme alanının jeoloji ve örnekleme haritası (Akbaş vd., 2011'den sadeleştirilerek alınmıştır) Figure 2. Geology and sampling maps of the study area (simplified from Akbaş et al., 2011)

\section{Bulgular ve tartışma}

4. Results and discussion

\subsection{Hidrojeokimya}

\subsection{Hydrogeochemistry}

Yeraltı sularının kimyasal bileşimi, suyun dokanakta olduğu kayacın kimyasal bileşimine, dokanak yüzeyi ve süresine, yeraltı suyunun akım hızına, sicaklığına, ortamın basıncına, iyon etkinliği ve ortak iyon etkinliğine, ortamın $\mathrm{pH}$ 'ına bağlıdır. Yeraltı sularında bulunan başlıca iyonlar $\mathrm{Ca}^{+2}, \mathrm{Mg}^{+2}, \mathrm{Na}^{+}, \mathrm{K}^{+}, \mathrm{Cl}^{-}, \mathrm{SO}_{4}{ }^{-2}$ ve $\mathrm{HCO}_{3}{ }^{-}$trr. Yeralt1 sularının kimyasal bileşimleri bu suların kullanım alanlarını ve kullanılabilme özelliklerini belirlemede büyük önem taşır (Yüksel, 2007).

İncelenen suların kimyasal analiz sonuçları Tablo 2'de verilmiştir. Yağışlı dönemde (Mayıs, 2016) incelenen suların sicaklıkları $13.60-15.80^{\circ} \mathrm{C}$ arasında; $\mathrm{pH}$ değerleri 6.92 - 7.64 arasında; elektriksel iletkenlikleri ise $258.80-416.00 \mu \mathrm{S} / \mathrm{cm}$ arasındadır. Kurak dönemde (Eylül, 2016) ise suların sicaklıkları $13.80-15.60{ }^{\circ} \mathrm{C}$ arasında; $\mathrm{pH}$ değerleri 7.20-7.84 arasında; elektriksel iletkenlikleri ise $245.70 \quad-399.70 \mu \mathrm{S} / \mathrm{cm}$ arasındadır (Tablo 2). 
Tablo 2. İncelenen yeraltı suların kimyasal analiz sonuçları ve içme suyu standartları (yağışlı dönem "M": May1s, 2016; kurak dönem "E": Eylül, 2016)

Table 2. Chemical analysis' results of investigated groundwaters and drinking water standards (rainy season "M": May, 2016; dry period "E”: September, 2016)

\begin{tabular}{|c|c|c|c|c|c|c|c|c|c|c|}
\hline \multirow{3}{*}{$\begin{array}{l}\text { Örnek } \\
\text { no }\end{array}$} & \multicolumn{2}{|c|}{ pH } & \multicolumn{2}{|c|}{ Sicaklık } & \multicolumn{2}{|c|}{ EC } & \multicolumn{2}{|c|}{$\mathbf{C a}^{+2}$} & \multicolumn{2}{|c|}{$\mathbf{M g}^{+2}$} \\
\hline & & & \multicolumn{2}{|c|}{$\left({ }^{\circ} \mathrm{C}\right)$} & \multicolumn{2}{|c|}{$(\mu \mathrm{S} / \mathrm{cm})$} & \multicolumn{2}{|c|}{$(\mathrm{mg} / \mathrm{L})$} & \multicolumn{2}{|c|}{$(\mathrm{mg} / \mathrm{L})$} \\
\hline & M & E & $\mathrm{M}$ & E & M & E & $\mathrm{M}$ & $\mathrm{E}$ & $\mathrm{M}$ & $\mathrm{E}$ \\
\hline AÇ-1 & 6.95 & 7.20 & 15.50 & 13.90 & 416.00 & 399.70 & 90.75 & 84.72 & 23.81 & 22.17 \\
\hline AÇ-2 & 7.64 & 7.84 & 15.80 & 15.00 & 258.80 & 245.70 & 45.49 & 45.74 & 18.08 & 17.38 \\
\hline AÇ-3 & 7.30 & 7.42 & 13.90 & 15.50 & 356.30 & 355.60 & 63.68 & 60.32 & 28.15 & 27.03 \\
\hline AÇ-4 & 7.33 & 7.27 & 14.80 & 15.60 & 313.00 & 324.20 & 68.40 & 66.97 & 14.64 & 15.66 \\
\hline AÇ-5 & 7.24 & 7.37 & 13.70 & 13.80 & 324.00 & 320.80 & 77.57 & 77.18 & 11.82 & 11.68 \\
\hline AÇ-6 & 6.96 & 7.20 & 13.60 & 15.30 & 351.10 & 355.00 & 83.47 & 80.85 & 14.51 & 13.56 \\
\hline AÇ-7 & 7.27 & 7.48 & 14.70 & 15.60 & 259.90 & 276.20 & 67.90 & 68.51 & 6.28 & 6.39 \\
\hline AÇ-8 & 7.04 & 7.36 & 15.10 & 15.00 & 330.20 & 342.70 & 83.32 & 82.93 & 9.97 & 9.98 \\
\hline AÇ-9 & 6.92 & 7.23 & 14.80 & 15.40 & 383.60 & 383.30 & 110.55 & 73.05 & 31.47 & 23.89 \\
\hline $\begin{array}{c}\text { TSE } \\
(\mathbf{2 0 0 5})\end{array}$ & \multicolumn{2}{|c|}{$6.5-9.5$} & \multicolumn{2}{|c|}{ - } & \multicolumn{2}{|c|}{2500} & \multicolumn{2}{|c|}{200.00} & \multicolumn{2}{|c|}{50.00} \\
\hline $\begin{array}{l}\text { WHO } \\
(2011)\end{array}$ & \multicolumn{2}{|c|}{$6.5-9.5$} & \multicolumn{2}{|c|}{-} & \multicolumn{2}{|c|}{-} & \multicolumn{2}{|c|}{-} & \multicolumn{2}{|c|}{ - } \\
\hline
\end{tabular}

Tablo 2. (devami)

Table 2. (continuing)

\begin{tabular}{|c|c|c|c|c|c|c|c|c|c|c|}
\hline \multirow{3}{*}{$\begin{array}{l}\text { Örnek } \\
\text { no }\end{array}$} & \multicolumn{2}{|c|}{$\mathbf{N a}^{+}$} & \multicolumn{2}{|c|}{$\mathbf{K}^{+}$} & \multicolumn{2}{|c|}{$\mathrm{Cl}^{-}$} & \multicolumn{2}{|c|}{$\mathrm{SO}_{4}^{-2}$} & \multicolumn{2}{|c|}{$\mathrm{HCO}_{3}{ }^{-}$} \\
\hline & \multicolumn{2}{|c|}{$(\mathrm{mg} / \mathrm{L})$} & \multicolumn{2}{|c|}{$(\mathrm{mg} / \mathrm{L})$} & \multicolumn{2}{|c|}{$(\mathrm{mg} / \mathrm{L})$} & \multicolumn{2}{|c|}{$(\mathrm{mg} / \mathrm{L})$} & \multicolumn{2}{|c|}{$(\mathrm{mg} / \mathrm{L})$} \\
\hline & $\mathrm{M}$ & $\mathrm{E}$ & $\mathrm{M}$ & E & $\mathrm{M}$ & $E$ & $\mathrm{M}$ & $\mathrm{E}$ & $M$ & $E$ \\
\hline AÇ-1 & 8.24 & 7.85 & 1.64 & 1.42 & 19.00 & 4.60 & 6.00 & 4.00 & 367.82 & 362.16 \\
\hline AÇ-2 & 3.90 & 4.25 & 0.78 & 0.73 & 21.00 & 1.77 & 3.00 & 1.00 & 195.56 & 227.49 \\
\hline AÇ-3 & 6.28 & 6.11 & 1.58 & 1.32 & 25.00 & 0.91 & 3.00 & 9.00 & 290.56 & 318.85 \\
\hline AÇ-4 & 3.88 & 3.67 & 0.60 & 0.54 & 37.00 & 0.25 & 3.00 & 1.00 & 218.09 & 278.30 \\
\hline AÇ-5 & 4.13 & 4.33 & 1.16 & 1.03 & 25.00 & 1.23 & 3.00 & 1.00 & 257.01 & 291.25 \\
\hline AÇ-6 & 8.88 & 9.01 & 0.48 & 0.54 & 17.00 & 1.96 & 8.00 & 4.00 & 308.32 & 348.40 \\
\hline AÇ-7 & 2.49 & 2.63 & 0.14 & 0.18 & 42.00 & 1.26 & 9.00 & 1.00 & 159.78 & 257.64 \\
\hline AÇ-8 & 4.16 & 4.24 & 1.68 & 1.52 & 20.00 & 1.83 & 2.00 & 0.80 & 275.41 & 301.45 \\
\hline AÇ-9 & 4.70 & 4.95 & 2.10 & 0.94 & 14.00 & 3.24 & 4.00 & 3.00 & 482.65 & 347.47 \\
\hline $\begin{array}{c}\text { TSE } \\
(\mathbf{2 0 0 5})\end{array}$ & \multicolumn{2}{|c|}{200.00} & \multicolumn{2}{|c|}{12.00} & \multicolumn{2}{|c|}{600.00} & \multicolumn{2}{|c|}{250.00} & \\
\hline $\begin{array}{l}\text { WHO } \\
(\mathbf{2 0 1 1})\end{array}$ & \multicolumn{2}{|c|}{200.00} & \multicolumn{2}{|c|}{ - } & \multicolumn{2}{|c|}{250.00} & \multicolumn{2}{|c|}{250.00} & \multicolumn{2}{|c|}{ - } \\
\hline
\end{tabular}


Tablo 2. (devami)

Table 2. (continuing)

\begin{tabular}{|c|c|c|c|c|c|c|c|c|c|c|}
\hline \multirow[t]{3}{*}{$\begin{array}{l}\text { Örnek } \\
\text { no }\end{array}$} & \multicolumn{2}{|c|}{ Mn } & \multicolumn{2}{|c|}{$\mathbf{N i}$} & \multicolumn{2}{|c|}{$\mathrm{Cr}$} & \multicolumn{2}{|c|}{$\mathbf{F e}$} & \multicolumn{2}{|c|}{ Al } \\
\hline & \multicolumn{2}{|c|}{$\mathrm{ppb}$} & \multicolumn{2}{|c|}{$\mathrm{ppb}$} & \multicolumn{2}{|c|}{$\mathrm{ppb}$} & \multicolumn{2}{|c|}{$\mathrm{ppb}$} & \multicolumn{2}{|c|}{$\mathrm{ppb}$} \\
\hline & $\mathrm{M}$ & $\mathrm{E}$ & $\mathrm{M}$ & $E$ & $\mathrm{M}$ & $\mathrm{E}$ & $\mathrm{M}$ & $E$ & $\mathrm{M}$ & $\mathrm{E}$ \\
\hline AÇ-1 & $<0.05$ & 0.06 & $<0.20$ & $<0.20$ & $<0.50$ & $<0.50$ & $<10.00$ & $<10.00$ & 2.00 & 3.00 \\
\hline AÇ-2 & $<0.05$ & 0.86 & $<0.20$ & $<0.20$ & $<0.50$ & $<0.50$ & $<10.00$ & $<10.00$ & 4.00 & 2.00 \\
\hline AÇ-3 & 0.28 & $<0.05$ & $<0.20$ & $<0.20$ & $<0.50$ & $<0.50$ & $<10.00$ & $<10.00$ & 4.00 & $<1.00$ \\
\hline AÇ-4 & 1.38 & 4.35 & $<0.20$ & $<0.20$ & $<0.50$ & $<0.50$ & $<10.00$ & 11.00 & 8.00 & 1.00 \\
\hline AÇ-5 & $<0.05$ & $<0.05$ & $<0.20$ & $<0.20$ & $<0.50$ & $<0.50$ & $<10.00$ & $<10.00$ & 3.00 & $<1.00$ \\
\hline AÇ-6 & 0.20 & 2.14 & $<0.20$ & $<0.20$ & $<0.50$ & $<0.50$ & $<10.00$ & $<10.00$ & 6.00 & $<1.00$ \\
\hline AÇ-7 & 0.13 & 0.32 & $<0.20$ & $<0.20$ & $<0.50$ & $<0.50$ & $<10.00$ & $<10.00$ & 2.00 & 2.00 \\
\hline AÇ-8 & $<0.05$ & $<0.05$ & $<0.20$ & $<0.20$ & $<0.50$ & $<0.50$ & $<10.00$ & 12.00 & 2.00 & $<1.00$ \\
\hline AÇ-9 & 52.11 & $<0.05$ & 1.10 & $<0.20$ & 17.30 & 11.30 & 569.00 & 11.00 & 612.00 & $<1.00$ \\
\hline $\begin{array}{c}\text { TSE } \\
(\mathbf{2 0 0 5})\end{array}$ & \multicolumn{2}{|c|}{50.00} & \multicolumn{2}{|c|}{20.00} & \multicolumn{2}{|c|}{50.00} & \multicolumn{2}{|c|}{200.00} & \multicolumn{2}{|c|}{200.00} \\
\hline $\begin{array}{l}\text { WHO } \\
\text { (2011) }\end{array}$ & \multicolumn{2}{|c|}{50.00} & \multicolumn{2}{|c|}{70.00} & \multicolumn{2}{|c|}{50.00} & \multicolumn{2}{|c|}{300.00} & \multicolumn{2}{|c|}{200.00} \\
\hline
\end{tabular}

Tablo 2. (devami)

Table 2. (continuing)

\begin{tabular}{|c|c|c|c|c|c|c|}
\hline \multirow[t]{3}{*}{$\begin{array}{l}\text { Örnek } \\
\text { no }\end{array}$} & \multicolumn{2}{|c|}{$\mathrm{Cu}$} & \multicolumn{2}{|c|}{ Zn } & \multicolumn{2}{|c|}{$\mathbf{P b}$} \\
\hline & \multicolumn{2}{|c|}{$\mathrm{ppb}$} & \multicolumn{2}{|c|}{$\mathrm{ppb}$} & \multicolumn{2}{|c|}{$\mathrm{ppb}$} \\
\hline & $\mathrm{M}$ & $\mathrm{E}$ & $M$ & $\mathrm{E}$ & $\mathrm{M}$ & $\mathrm{E}$ \\
\hline AÇ-1 & 0.50 & 0.50 & $<0.50$ & $<0.50$ & $<0.10$ & $<0.10$ \\
\hline AÇ-2 & 0.30 & 0.20 & $<0.50$ & $<0.50$ & $<0.10$ & $<0.10$ \\
\hline AÇ-3 & 0.50 & 0.40 & 1.00 & 0.90 & $<0.10$ & $<0.10$ \\
\hline AÇ-4 & 0.30 & 0.50 & 0.50 & 0.60 & $<0.10$ & $<0.10$ \\
\hline AÇ-5 & 0.40 & 0.40 & $<0.50$ & $<0.50$ & $<0.10$ & $<0.10$ \\
\hline AÇ-6 & 1.20 & 2.50 & 6.50 & 5.20 & $<0.10$ & 0.20 \\
\hline AÇ-7 & 0.40 & 0.40 & $<0.50$ & 1.80 & $<0.10$ & 0.20 \\
\hline AÇ-8 & 0.30 & 0.20 & $<0.50$ & $<0.50$ & $<0.10$ & $<0.10$ \\
\hline AÇ-9 & 1.30 & 0.40 & 2.10 & 0.70 & 4.50 & $<0.10$ \\
\hline $\begin{array}{c}\text { TSE } \\
(\mathbf{2 0 0 5})\end{array}$ & \multicolumn{2}{|c|}{2000.00} & \multicolumn{2}{|c|}{-} & \multicolumn{2}{|c|}{10.00} \\
\hline $\begin{array}{l}\text { WHO } \\
(2011)\end{array}$ & \multicolumn{2}{|c|}{2000.00} & \multicolumn{2}{|c|}{-} & \multicolumn{2}{|c|}{10.00} \\
\hline
\end{tabular}

Suların sıcaklık değișimleri dönemsel olarak değerlendirildiğinde, genel olarak sıcaklıkların kurak dönemde arttığı görülmüştür (Şekil 3a).

Yağışlı dönemde yeraltı sularına yağışlar nedeniyle su ilavesi olduğundan mevcut suların sıcaklığı düşmektedir. Genel olarak incelenen suların elektriksel iletkenlikleri (EC) yağışlı dönemde daha düşüktür (Şekil 3b). Yağışlı dönemde suyun elektriksel iletkenliğinin düşük olması, yağıştan beslenmeye bağlı olarak yüksek hidrolik eğim ve hızlı akıșla ilişkilidir. Yağış suyunun hızlı hareketi süresince su-kayaç etkileşimi daha düşük olmaktadır. Yağışların beslenme üzerindeki etkisinin azaldığı kurak dönemde yeraltı suyu akım hızının yavaşlamasına, sukayaç etkileşim süresinin artmasına neden olmaktadır. Su- kayaç etkileşiminin artması suyun elektriksel iletkenliğini arttırmaktadır. Yağışlı dönemde ölçülen daha düşük $\mathrm{pH}$ değerinin, akiferi besleyen yağış sularının pH'ının düşük olması ya da suyun dolaşım ortamında $\operatorname{artan} \mathrm{CO}_{2}$ ile ilişkili olduğu düşünülmektedir (Şekil 3c) (Güler vd., 2017). Suyun $\mathrm{CO}_{2}$ 'ce zenginleşmesi yüzeye yakın kesimlerde, toprak seviyesinde oldukça 
etkindir. Yüzeye yakın bölgede, organik maddelerin mikroorganizmalar yardımıyla oksidasyon süreci boyunca ve bitki köklerinin solunumu ile $\mathrm{CO}_{2}$ oluşmaktadır (Milanovic, 1981). Karbonatların çözünürlüğü ortamdaki

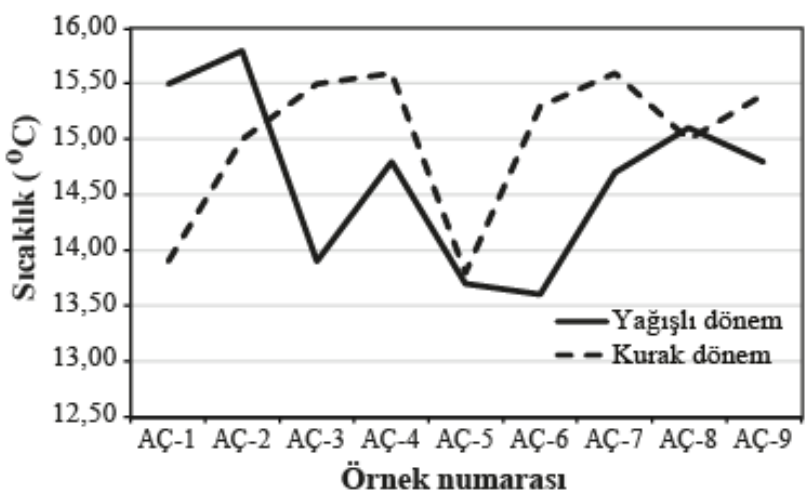

(a)
$\mathrm{CO}_{2}$ miktarı ve suyun $\mathrm{pH}^{\prime} 1$ ile kontrol edilmektedir. Ortamdaki $\mathrm{CO}_{2}$ miktarı arttıkça ve pH azaldıkça karbonatların çözünürlüğü artar.

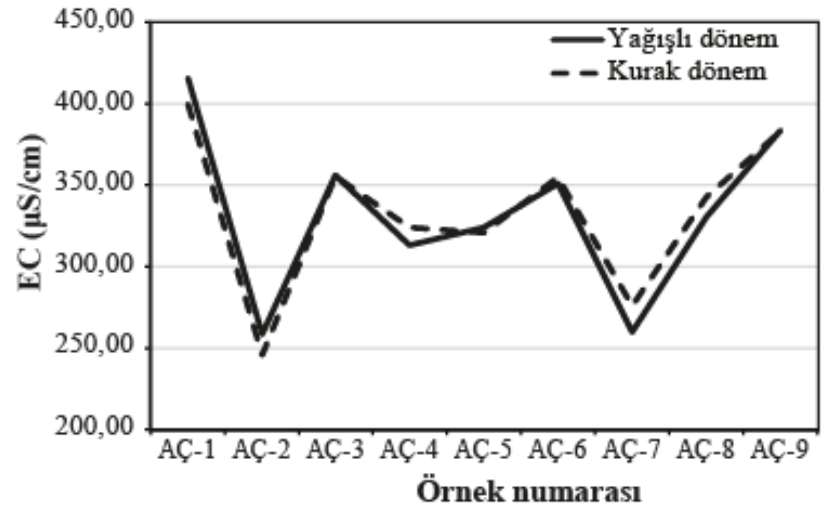

(b)

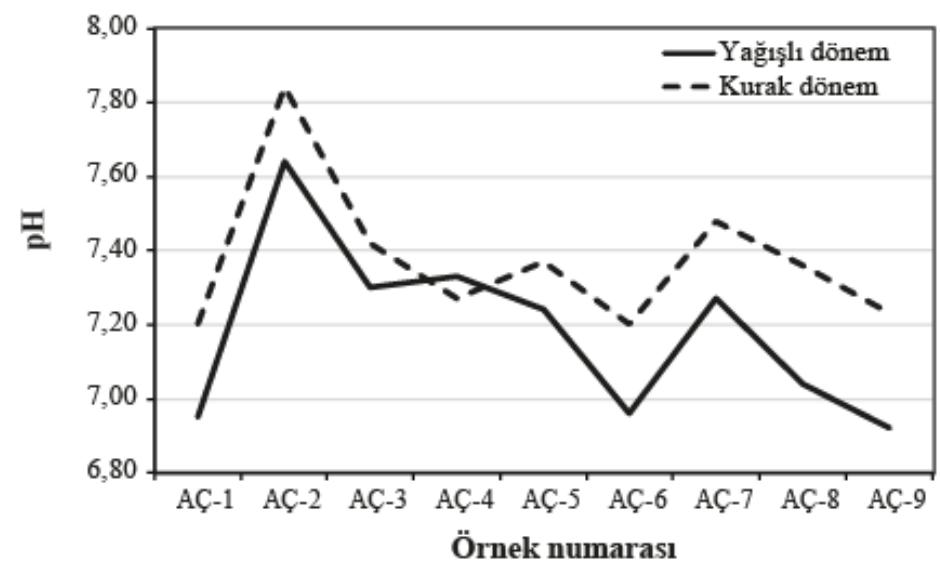

(c)

Şekil 3. Suların a) Sıcaklık, b) EC, c) pH değerlerinin dönemsel değişimleri

Figure 3. Seasonal changes of a) temperature, b) EC, c) $p H$ values of groundwaters

Su örneklerinin kurak dönem (Eylül, 2016) kimyasal analiz sonuçlarına göre Schoeller diyagramı çizilmiş ve incelenen suların iyonlarını birleştiren doğruların birbirlerine paralel ya da paralele yakın olduğu, dolayısıyla bu sularin benzer litolojideki akiferlerden beslendiği ortaya konmuştur (Şekil 4).

İncelenen suların tipleri Tablo 3 'te verilmiştir. Yağışlı ve kurak dönemde AÇ-1, AÇ-2, AÇ-3 ve AÇ-9 numaralı su örnekleri $\mathrm{Ca}-\mathrm{Mg}$ $\mathrm{HCO}_{3}{ }^{\prime}{ }^{1} 1$ su, AÇ-5 ve AÇ-8 numaralı su örnekleri ise $\mathrm{Ca}-\mathrm{HCO}_{3}$ 'lı su tipindedir. AÇ-4, AÇ-6, AÇ-7 numaralı su örneklerinin tipleri ise dönemsel farklılıklar göstermektedir. AÇ-4 ve AÇ-7 numaralı su örneklerinde yağışlı dönemde $\mathrm{Cl}^{-}$içeriğinin yüksek olması bu suların sığ yeraltı suyu dolaşımına sahip ve güncel yağışlardan etkilendiklerini işaret etmektedir. AÇ-6 numaralı su örneğinde ise yağışlı dönemde artan $\mathrm{Mg}^{+2}$ içeriği, bu dönemde yeraltı suyunun düşük $\mathrm{pH}$ değerine bağlı olarak karbonatlar içerisindeki dolomitin çözünürlügüünun artması ile ilişkili olmalıdır. 


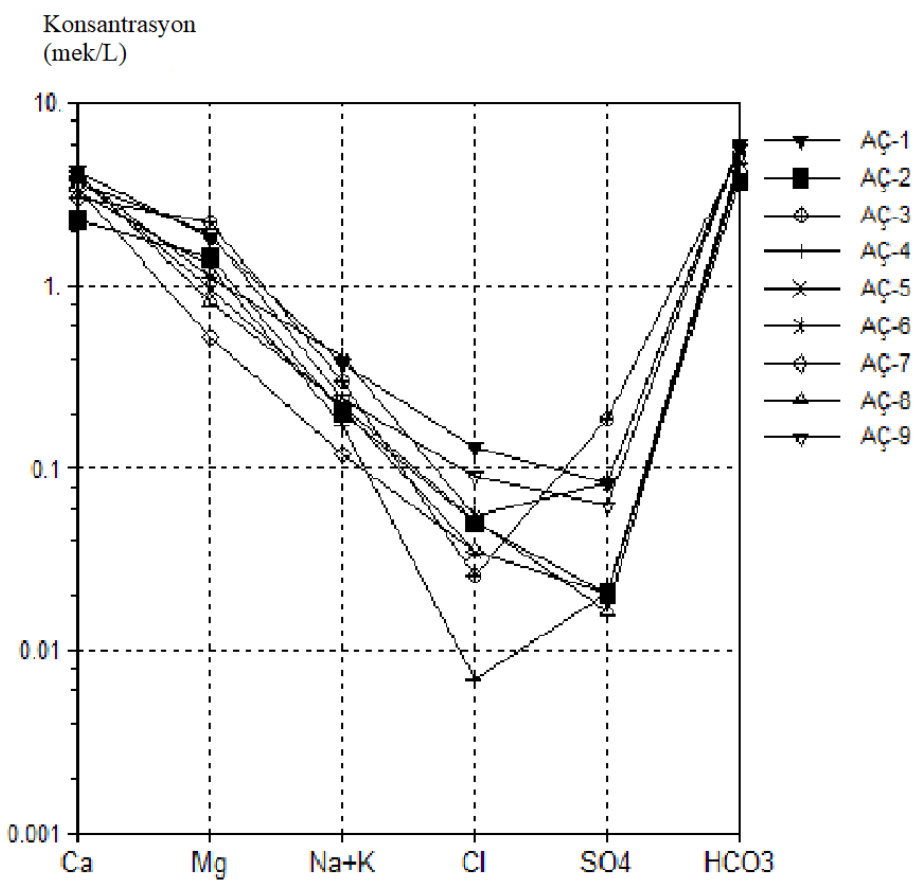

Şekil 4. İncelenen suların Eylül (2016) ayı kimyasal analiz sonuçlarının Schoeller diyagramında gösterilmesi

Figure 4. Schoeller diagram of investigated groundwaters (September, 2016)

Tablo 3. İncelenen suların tipleri

Table 3. Water types of investigated groundwaters

\begin{tabular}{|c|c|c|}
\hline $\begin{array}{l}\text { Örnek } \\
\text { No }\end{array}$ & $\begin{array}{l}\text { Su tipi } \\
\text { (Kurak } \\
\text { dönem) }\end{array}$ & $\begin{array}{l}\text { Su tipi } \\
\text { (Yağışlı dönem) }\end{array}$ \\
\hline AÇ-1 & $\mathrm{Ca}-\mathrm{Mg}-\mathrm{HCO}_{3}$ & $\mathrm{Ca}-\mathrm{Mg}-\mathrm{HCO}_{3}$ \\
\hline AÇ-2 & $\mathrm{Ca}-\mathrm{Mg}-\mathrm{HCO}_{3}$ & $\mathrm{Ca}-\mathrm{Mg}-\mathrm{HCO}_{3}$ \\
\hline AÇ-3 & $\mathrm{Ca}-\mathrm{Mg}-\mathrm{HCO}_{3}$ & $\mathrm{Ca}-\mathrm{Mg}-\mathrm{HCO}_{3}$ \\
\hline AÇ-4 & $\mathrm{Ca}-\mathrm{Mg}-\mathrm{HCO}_{3}$ & $\mathrm{Ca}-\mathrm{Mg}-\mathrm{HCO}_{3}-\mathrm{Cl}$ \\
\hline AÇ-5 & $\mathrm{Ca}-\mathrm{HCO}_{3}$ & $\mathrm{Ca}-\mathrm{HCO}_{3}$ \\
\hline AÇ-6 & $\mathrm{Ca}-\mathrm{HCO}_{3}$ & $\mathrm{Ca}-\mathrm{Mg}-\mathrm{HCO}_{3}$ \\
\hline AÇ-7 & $\mathrm{Ca}-\mathrm{HCO}_{3}$ & $\mathrm{Ca}-\mathrm{HCO}_{3}-\mathrm{Cl}$ \\
\hline AÇ-8 & $\mathrm{Ca}-\mathrm{HCO}_{3}$ & $\mathrm{Ca}-\mathrm{HCO}_{3}$ \\
\hline AÇ-9 & $\mathrm{Ca}-\mathrm{Mg}-\mathrm{HCO}_{3}$ & $\mathrm{Ca}-\mathrm{Mg}-\mathrm{HCO}_{3}$ \\
\hline
\end{tabular}

İncelenen suların içme amaçlı kullanımına uygunluğunu belirlemek amaciyla, kimyasal bileşimleri Türk Standartları Enstitüsü (TSE) (2005) ve Dünya Sağlık Örgütü (WHO) (2011) Yönetmeliği standartlarında belirlenen maksimum limit değerleri ile karşılaştırılmıştır. İncelenen suların genel olarak pH, EC, majör anyon, katyon, potansiyel toksik element içeriklerinin içme suyu standartlarına uygun olduğu belirlenirken, sadece AÇ-9 numaralı örneğin $\mathrm{Mn}, \mathrm{Fe}$ ve $\mathrm{Al}$ konsantrasyonlarının yağışlı dönemde içme suyu standartlarının üst sınır değerlerinin üzerinde olduğu belirlenmiştir (Tablo 2).

\subsection{Majör anyon ve katyonlar 4.2. Major anions and cations}

İncelenen suların, yağışlı dönemde, $\mathrm{Ca}^{+2}$ iyon içerikleri $45.49-110.55 \mathrm{mg} / \mathrm{l} ; \mathrm{Mg}^{+2}$ iyon içerikleri 6.28- $31.47 \mathrm{mg} / \mathrm{l} ; \mathrm{Na}^{+}$iyon içerikleri $2.49-8.88$ $\mathrm{mg} / \mathrm{l} ; \mathrm{K}^{+}$iyon içerikleri $0.14-2.10 \mathrm{mg} / \mathrm{l} ; \mathrm{Cl}^{-}$iyon içerikleri 14.00 - $42.00 \mathrm{mg} / \mathrm{l} ; \mathrm{SO}_{4}^{-2}$ iyon içerikleri 2.00- $9.00 \mathrm{mg} / \mathrm{l} ; \mathrm{HCO}_{3}{ }^{-}$iyon içerikleri ise 159.78 $482.65 \mathrm{mg} / \mathrm{l}$ arasında değişmektedir. Kurak dönemde ise suların $\mathrm{Ca}^{+2}$ iyon içerikleri 45.74$84.72 \mathrm{mg} / \mathrm{l}$ arasında; $\mathrm{Mg}^{+2}$ iyon içerikleri 6.39$27.03 \mathrm{mg} / \mathrm{l}$ arasında; $\mathrm{Na}^{+}$iyon içerikleri 2.63- 9.01 $\mathrm{mg} / \mathrm{l}$ arasında; $\mathrm{K}^{+}$iyon içerikleri $0.18-1.52 \mathrm{mg} / \mathrm{l}$ arasında; $\mathrm{Cl}^{-}$iyon içerikleri $0.25-4.60 \mathrm{mg} / \mathrm{l}$ arasında; $\mathrm{SO}_{4}^{-2}$ iyon içerikleri $0.80-9.00 \mathrm{mg} / \mathrm{l}$ arasında; $\mathrm{HCO}_{3}{ }^{-}$iyon içerikleri 227.49- 362.16 $\mathrm{mg} / \mathrm{l}$ arasindadir (Tablo 2).

Genel olarak incelenen suların $\mathrm{Ca}^{+2}, \mathrm{Mg}^{+2}$ ve $\mathrm{Na}^{+}$ içeriklerinde belirgin dönemsel değişimler gözlenmezken, $\mathrm{K}^{+}, \mathrm{Cl}^{-}$ve $\mathrm{SO}_{4}{ }^{-2}$ içeriklerinin yağış̧ 1 dönemde, $\mathrm{HCO}_{3}{ }^{-}$içeriklerinin ise kurak dönemde yüksek olduğu belirlenmiştir (Şekil 5). Sularda $\mathrm{K}^{+}$, $\mathrm{Cl}^{-}$ve $\mathrm{SO}_{4}^{-2}$ iyonlarının yağış̧ı dönemde daha yüksek olması bu iyonların kökenlerinin yağışlarla ilişkili olduğunu (özellikle $\mathrm{Cl}^{-}$) ve yağışlı dönemde düşük $\mathrm{pH}$ değerleri ile ilişkili artan su- kayaç çözünmesine bağlıdır. 
İncelenen sularda $\mathrm{Ca}^{+2}$ iyonunun kökenini, bölgede yüzeyleme veren kireçtaşlarının çözünmesi ile volkanik kayaçlardaki anortit, piroksen ve amfibol gibi silikat minerallerinin bünyesinde bulunan $\mathrm{Ca}^{+2}$ iyonunun çözünmesi oluşturmaktadır. Sularda bulunan $\mathrm{Mg}^{+2}$ iyonunun kökenini Üst MiyosenPliyosen yaşlı volkanik kayaçlar içerisinde bulunan olivin, biyotit, horblend gibi magnezyum bileşenli minerallerin çözünmesi ve Alibonca Formasyonu'na ait sedimanter birimler içerisinde bulunan dolomitin çözünmesi oluşturmaktadır (Şener \& Güneş, 2015). $\mathrm{K}^{+}$, çalışma alanında yüzeylenen volkanik kayaçların bünyesinde bulunan mika ve feldspat minerallerinin çözünmesiyle yeraltı sularına geçmiştir. İncelenen sularda $\mathrm{Na}^{+}$'nın kaynağ 1 , bölgede bulunan volkanik kayaçlar içerisindeki $\mathrm{Na}$ 'lu feldspatların çözünmesiyle ilişkidir. Ayrıca, Alibonca Formasyonu'na ait denizel çökeller içerisindeki tuzlu seviyelerin çözünmesi de yeraltı sularında bu iyonun kökenini oluşturmaktadır. Sularda kurak dönemi temsil eden Ekim ayında artan $\mathrm{HCO}_{3}{ }^{-}$ iyonu yeraltı sularına bölgede yüzeyleme veren kireçtaşlarının $\mathrm{CO}_{2}{ }^{\prime}$ li sular tarafından çözünmesi ve silikat minerallerinin hidrolizi sonucu geçmiştir. İncelenen sularda $\mathrm{SO}_{4}{ }^{-2}$ iyonunun kaynağ 1 , pirit $\left(\mathrm{FeS}_{2}\right)$ mineralinin oksidasyonu ile oluşan $\mathrm{FeSO}_{4}$, göl ve deniz sedimanları içerisinde bulunan jips ve anhidrit minerallerinin çözünmesi ve yağmur suları olduğu düşünülmektedir. Sularda $\mathrm{Cl}^{-}$iyonunun kaynağ1 ise yağış suları ile denizel sedimanlar içerisindeki tuzlu seviyelerin çözünmesi oluşturmaktadır (Öztekin Okan \& Güven, 2019).

$\mathrm{HCO}_{3}{ }^{-}$içerikleri kurak dönemde yağışlı döneme oranla biraz daha yüksektir. Kurak dönemde, artan su- kayaç etkileşim süresine bağlı olarak karbonatların çözünmesindeki artış ayrıca, silikatların (olivin, piroksen, plajiyoklaz, alkali feldspat gibi) hidrolizi $\mathrm{HCO}_{3}{ }^{-}$artışında etkindir (Kimball, 1981; Kebede vd., 2005).

Sülfatın yeraltı sularındaki kökeni i) doğal ve yapay sülfat içeren yağışlar, ii) sülfat içeren evaporitlerin çözünmesi, iii) deniz suyu girişimi, iv) antropojenik kirleticiler (örn. Evsel atıklar, deterjan ve tarımsal gübreler) ile ilişkilidir (Han vd., 2016; Kim \& Park, 2016; Salem \& ElBayumy, 2016). Diğer su örneklerinden farklı olarak AÇ-3 nolu su örneğinde kurak dönemde analiz edilen yüksek $\mathrm{SO}_{4}{ }^{-2}$ içeriğinin kökeninde yağış suları ve su-kayaç etkileşiminin yanında, bu örnekleme noktasının yakınında bulunan hayvan besi ahırlarının ayrıca tarımsal gübrelerin de etkili olduğu söylenebilir.

\subsection{Potansiyel toksik elementler \\ 4.3. Potentially toxic elements}

Potansiyel toksik elementlerin varlığ 1 suyun hangi tür kayaçlarla etkileşim içerisinde olduğunu göstermesinin yanında su içerisindeki miktarları da suyun kalitesini etkilemektedir. İncelenen suların alüminyum $(\mathrm{Al}), \operatorname{krom}(\mathrm{Cr})$, bakır $(\mathrm{Cu}), \operatorname{demir}(\mathrm{Fe})$, mangan (Mn) ve çinko (Zn) konsantrasyonlarının dönemsel değişimleri Şekil 6'da verilmiştir. Genel olarak suların nikel (Ni) ve kurşun $(\mathrm{Pb})$ konsantrasyonları her iki dönemde de sirasiyla $<0.20 \mathrm{ppb}$ ve $<0.10 \mathrm{ppb}$ olduğundan grafikte gösterilmemiştir. Suların $\mathrm{Al}, \mathrm{Cu}$ ve $\mathrm{Zn}$ konsantrasyonları yağışlı dönemde daha yüksek ölçülmüşken, Mn ve Fe konsantrasyonlar1 kurak dönemde daha yüksektir (Tablo 2, Şekil 6). İncelenen sularda sadece AÇ-9 numaralı suda yağışlı dönemde potansiyel toksik element konsantrasyonları diğer sulara oranla oldukça yüksektir.

Fe'in jeokimyasal özellikleri sıkı bir şekilde oksijen, kükürt ve karbona bağlıdır. Fe, killerde, karbonatlarda (siderit), sülfit (pirit) ve oksitlerde (götit, amorf demir oksitler) bol bulunur. Fe, killerde ve diğer silikatlarda reaktif değilken, oksitlerde, sülfitlerde ve karbonatlarda reaktiftir (Heerdink \& Griffioen, 2008; Olivier, 2012). Yeraltı suyunda demir çoğunlukla $\mathrm{Fe}^{+2}$ formunda bulunur (Hem, 1989; Olivier, 2012).

Çalışma alanındaki sularda Fe konsantrasyonu hem yağışlı hem de kurak dönemde $<10.00$ ppb'dir. Kurak dönemde sadece AÇ-4, AÇ-8 ve AÇ-9 numaralı sularda 11.00- 12.00 ppb Fe belirlenmiştir (Tablo 2). Çalışma alanında Keban Metamorfitleri'ne ait rekristalize kireçtaşlarında $\mathrm{Fe}_{2} \mathrm{O}_{3}$ konsantrasyonu \%3.77\%5.70 arasında değişirken, Alibonca Formasyonu'na ait karbonat ve killi kireçtaşlarının $\mathrm{Fe}_{2} \mathrm{O}_{3}$ konsantrasyonu \%0.19\%4.17 arasindadır. Alt Miyosen- Pliyosen yaşlı volkanitler ise \% 9.40- \%9.82 arasında $\mathrm{Fe}_{2} \mathrm{O}_{3}$ içermektedir (Tablo 4). AÇ-4, AÇ-8 ve AÇ-9 numaralı sularda kurak dönemde belirlenen $\mathrm{Fe}$, sulara beslenme alanı içerisinde bulunan volkanitlerin içerisindeki piroksen, amfibol, magnetit, pirit, biyotit gibi demirli minerallerin, ayrıca bol silisli kumtaşı gibi sedimanter kayaçların bünyesindeki demirli minerallerin çözünmesi ile geçmiştir (Hem, 1989; Şahinci, 1991). 

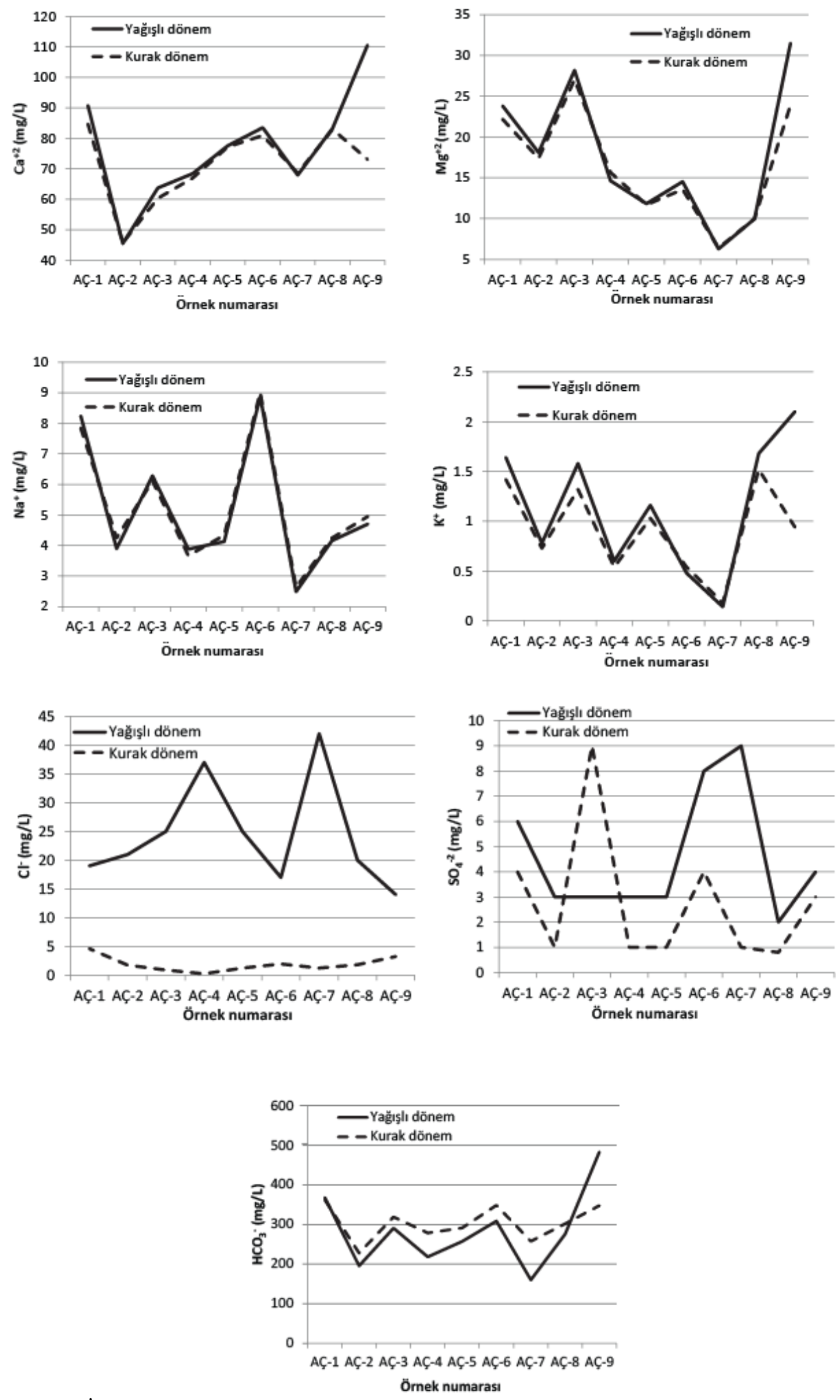

Şekil 5. İncelenen suların majör anyon katyon içeriklerinin dönemsel değişimleri

Figure 5. Seasonal changes of major anions and cations of investigated groundwaters 
Tablo 4. Çalışma alanında yüzeyleyen kayaçların $\mathrm{Fe}_{2} \mathrm{O}_{3}, \mathrm{MnO}$ ve $\mathrm{Al}_{2} \mathrm{O}_{3}$ içerikleri

Table 4. $\mathrm{Fe}_{2} \mathrm{O}_{3}, \mathrm{MnO}$ and $\mathrm{Al}_{2} \mathrm{O}_{3}$ contents of rocks outcropping in the study area

\begin{tabular}{lccc}
\hline & $\begin{array}{c}\text { Permo- Triyas yaşlı Keban } \\
\text { Metamorfitleri'ne ait } \\
\text { rekristalize kireçtaşları }\end{array}$ & $\begin{array}{c}\text { Alt Miyosen yaşlı } \\
\text { karbonat ve killi } \\
\text { kireçtaşları }\end{array}$ & $\begin{array}{c}\text { Alt Miyosen- } \\
\text { Pliyosen yaşlı } \\
\text { volkanitler }\end{array}$ \\
\hline $\mathrm{Fe}_{2} \mathrm{O}_{3}(\%)$ & $3.77-5.70$ & $0.19-4.17$ & $9.40-9.82$ \\
$\mathrm{MnO}(\%)$ & $0.01-0.02$ & $0.01-0.05$ & $0.14-0.15$ \\
$\mathrm{Al}_{2} \mathrm{O}_{3}(\%)$ & $10.53-15.50$ & $0.98-6.21$ & $15.78-15.91$ \\
\hline
\end{tabular}

Oksijensiz ortamda yeraltı suyundaki $\mathrm{Fe}^{+3}$ 'ün, $\mathrm{Fe}^{+2}$ ye indirgenmesiyle kontrol edilebilir (Bondu vd., 2018). Anoksik koşullar altında ferrihidritin $\left(\mathrm{Fe}(\mathrm{OH})_{3}\right)$ çözünmesi ve $\mathrm{Fe}^{+2}$ oluşumu aşağıdaki eşitlikte gösterilmiştir (Clark, 2015):

$\mathrm{Fe}(\mathrm{OH})_{3}+3 \mathrm{H}^{+} \leftrightarrow \mathrm{Fe}^{+2}+3 \mathrm{H}_{2} \mathrm{O}$

Kurak dönemde, AÇ-4, AÇ-8 ve AÇ-9 numaralı sulardaki $\mathrm{Fe}$ konsantrasyonlarının, oksijensiz ortamda Fe'in indirgenmesi mekanizmasına bağlı olarak kontrol edildiği düşünülmektedir.

Oksik ve suyun pH'ının düşük olduğu yağışlı dönemde $\mathrm{Fe}^{+2}$ 'nin $\mathrm{Fe}^{+3}$ 'e yükseltgenmesi aşağıdaki gibidir (Majkic Dursun vd., 2015):

$\mathrm{Fe}^{+2}+\mathrm{O}_{2}+2 \mathrm{H}^{+} \leftrightarrow \mathrm{Fe}^{+3}+2 \mathrm{OH}^{-}$

Yağışlı dönemde AÇ-9 numaralı örnekte oldukça yüksek konsantrasyonlarda bulunan $\mathrm{Fe}$ ise oksijenli ortamda Fe'in yükseltgenmesi ile kontrol edilmektedir.

Yerkabuğunda 950 ppm, ultrabazik kayaçlarda $1.62 \times 10^{3} \mathrm{ppm}$, baziklerde $1.5 \times 10^{3}$, granitlerde $6 \times 10^{2} \mathrm{ppm}$ ve karbonatl kayalarda ise $1.1 \times 10^{3}$ ppm kadar Mn bulunur (Şahinci, 1991). Mn, yaygın silikat minerallerinin hiçbirinin temel bir bileşeni değildir, ancak silikat yapılarında $\mathrm{Fe}, \mathrm{Mg}$ veya $\mathrm{Ca}$ 'un yerini alabilir. Çalışma alanında Keban Metamorfitleri'ne ait rekristalize kireçtaşlarının $\mathrm{MnO}$ içeriği \%0.01- \%0.02 arasında, Alt Miyosen yaşlı karbonat ve killi kireçtaşlarında \%0.01$\% 0.05$ arasında, Alt Miyosen- Pliyosen yaşlı volkanitlerde ise \%0.14- \%0.15 arasinda analiz edilmiştir (Tablo 4). İncelenen yeraltı sularında Mn'ın kökeni, iyon alış-verişine bağlı olarak kireçtaşlarında kalsit ayrıca, volkanik kayaçlar içerisindeki olivin, piroksen ve amfibol minerallerinde $\mathrm{Ca}, \mathrm{Mg}$ ve Fe'in yerini alan Mn'ın çözünmesi ile ilişkidir (Hem, 1989).

Mn ve $\mathrm{Fe}$ bazı kimyasal özellikler yönünden benzerlik göstermelerine rağmen, bazı kimyasal davranışlarında farklılıklar gösterirler. Suların Mn konsantrasyonların Fe'e benzer şekilde kurak dönemde daha yüksek olması yeraltı sularında $\mathrm{Mn}$ hidrojeokimyasal davranışının $\mathrm{Fe}$ ile aynı mekanizma ile kontrol edildiğini göstermektedir. İncelenen yeraltı sularında $\mathrm{Mn}$ çözünürlüğünü $\mathrm{pH}$ ve oksidasyon- redüksiyon koşulları etkilemektedir (Şahinci, 1991).

Al, yer kabuğunda önemli miktarda bulunmasına karşın az çözünmesi nedeniyle yeraltı sularında önemsiz miktarlarda bulunur. Genellikle yeraltı sularında 0.005- $0.30 \mathrm{ppm}$ arasında $\mathrm{Al}$ izlenirken, asidik yeraltı sularında bu değer 100 ppm'e erişebilir (Şahinci, 1991). Çalışma alanında geniş alanlarda yayılım sunan Alt Miyosen yaşlı karbonat ve killi kireçtaşlarının $\mathrm{Al}_{2} \mathrm{O}_{3}$ içeriğ $\%$ 0.98 - 6.21 arasinda iken Keban Metamorfitlerine ait rekristalize kireçtaşları ile Alt MiyosenPliyosen yaşlı volkanitlerde sırasıyla \% 10.5315.50 ve $\%$ 15.78- 15.91 arasindadır (Tablo 4). İncelenen yeraltı sularında Al'un kökeni Alt Miyosen yaşlı denizel çökeller içerindeki killer ile volkanik kayaçların bünyesinde bulunan feldspat, feldspatoid, mika ve amfibol gibi silikat minerallerinin çözünmesi ile ilişkilidir (Hem, 1989). Yağışlı dönemde yeraltısularında bulunan Al konsantrasyonunu kontrol eden baskın kimyasal süreç, oksijenli ortamda alüminyum hidroksitin oksidasyonudur. Ayrıca, bu dönemde daha yüksek konsantrasyonlarda bulunan Al, kil mineralleri tarafından soğrulmuş Al'un asidik yağış suları tarafından yıkanması ile yeraltı sularına geçmiştir. 

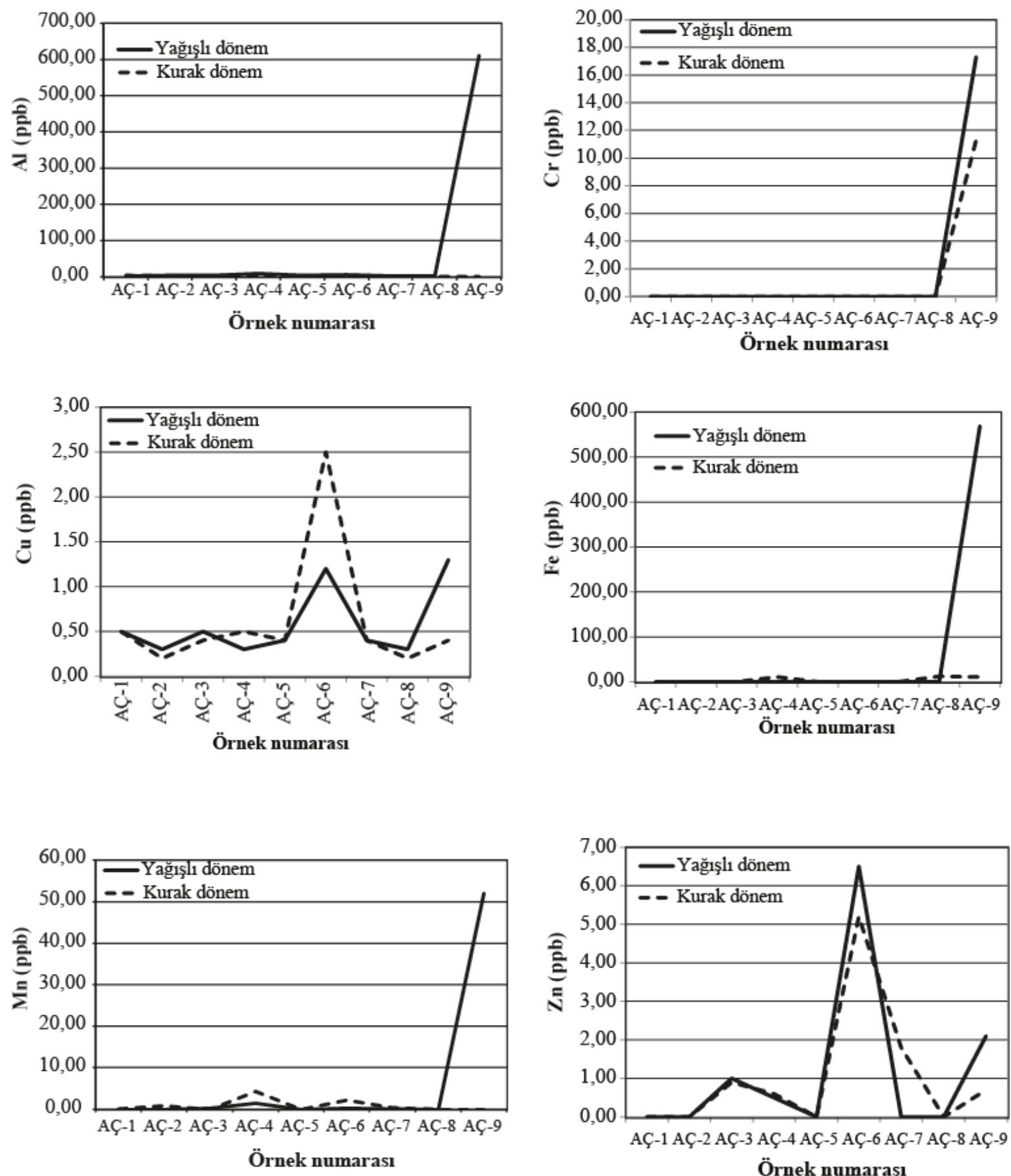

Şekil 6. İncelenen suların potansiyel toksik element konsantrasyonlarının dönemsel değișimleri

Figure 6. Seasonal changes of potentially toxic element concentrations of investigated groundwaters

Çalışma alanı içerisindeki yeraltı sularının $\mathrm{Ni}, \mathrm{Cr}$, $\mathrm{Pb}, \mathrm{Cu}$ ve $\mathrm{Zn}$ içerikleri yeraltı sularına su- kayaç etkileşimine bağlı olarak geçmiştir. Bu potansiyel toksik element konsantrasyonlarını kontrol eden diğer bir faktör de kil mineralleri tarafindan absorbe edilen bu metallerin akiferdeki $\mathrm{pH}$ - Eh koşullarına bağlı olarak gösterdikleri hidrojeokimyasal davranışlardır. AÇ-6 numaralı yeraltı suyunda diğer yeraltı su örneklerine oranla daha yüksek konsantrasyonlarda $\mathrm{Cu}, \mathrm{Pb}$ ve $\mathrm{Zn}$ belirlenmiştir. AÇ-6 numaralı keson kuyudan alınan sığ dolaşımlı yeraltı suyundaki daha yüksek konsantrasyonlarda tespit edilen bu potansiyel toksik elementlerin diğer bir kaynağı bölgede tarımsal faaliyetlerde kullanılan tarımsal gübreler ve ürün arttırıcı diğer kimyasallardır.

$\mathrm{Ni}, \mathrm{Cr}, \mathrm{Cu}, \mathrm{Zn}$ ve $\mathrm{Pb}$ gibi ağır metaller ile diğer kirleticiler $\mathrm{Fe}, \mathrm{Mn}$ ve $\mathrm{Al}$ hidroksitleri tarafindan kuvvetli bir şekilde absorbe edilirler. Yağış̧1 dönemde, yeraltı suyunun $\mathrm{pH}$ 'ının daha düşük olduğu dönemde, $\mathrm{Fe}, \mathrm{Al}$ ve $\mathrm{Mn}$ tarafindan absorbe edilen bu metaller çözünmeye bağlı olarak yeraltı suyuna geçerler (Clark, 2015). Bu nedenle, AÇ-9 
numaralı yeraltı suyunda yüksek $\mathrm{Fe}, \mathrm{Mn}$, Al konsantrasyonlarına bağlı olarak diğer potansiyel toksik element konsantrasyonları da diğer sulara oranla daha yüksektir. AÇ-9 numaralı yeraltı suyunda genel olarak belirlenen yüksek konsantrasyonlardaki potansiyel toksik element içerikleri örneğin alındığı sondaj kuyusu çevresinde yapılan bahçe tarında kullanılan kimyasal gübreler ile ilişkili olabilir. AÇ-9 numaralı su örneğinin alındığı sondaj kuyusu Keban Baraj Gölü'ne çok yakın bir noktada açılmıştır. Yağış̧ı dönemde AÇ-9 numaralı suda yüksek konsatrasyonlarda belirlenen $\mathrm{Fe}, \mathrm{Mn}, \mathrm{Al}$, diğer potansiyel toksik elementler yağışlı dönemde yükselen yüzey suyu seviyesine bağlı olarak baraj gölü ile akifer arasındaki hidrodinamik bir ilişkinin varlığını da işaret edebilir.

\section{Sonuçlar}

\section{Conclusions}

Çalışma alanında incelenen suların akiferi Alibonca Formasyonu'na ait kireçtaşlarıdır. Sular genel olarak $\mathrm{Ca}-\mathrm{Mg}-\mathrm{HCO}_{3}$ tipindedir. Su-kayaç etkileşimi, iyon yer değişimi, yeraltı suyunun $\mathrm{pH}$ değeri, oksidasyon- redüksiyon tepkimeleri, kil mineralleri- su etkileşimi yeraltı sularının majör anyon- katyon ve potansiyel toksik element içeriklerini kontrol eden baskın mekanizmalardır. Sahile yakın noktada açılan sondaj kuyusu dışındaki kuyu ve çeşme suları majör anyon, katyon ve potansiyel toksik elementler açısından içme amaçlı kullanıma uygundur. Ancak, özellikle besi ahırları ile tarım arazileri yakınında açılan sondaj kuyu sularında daha yüksek $\mathrm{SO}_{4}{ }^{-2}, \mathrm{Cu}, \mathrm{Pb}$ ve $\mathrm{Zn}$ içeriklerinin belirlenmesi bu etkenlerin ilerleyen y1llarda yeraltı su kalitesi üzerinde olumsuz etki oluşturacağını düşündürmektedir. Sığ dolaşımlı yeraltı sularında bu etkiler daha yoğun bir şekilde belirlenmiştir. Yağışlı dönemde Keban Baraj Gölü’nün su seviyesinin yükselmesine bağl1 olarak kıyıya yakın bölgede açılan sondaj kuyu suyunun majör anyon, katyon ve potansiyel toksik element içeriğinin, bu dönemde baraj gölünün akifere olan hidrodinamik etkisi ile ilişkili olduğu düşünülmektedir. Yöre halkının bu bölgelerde sondaj kuyusu açmamaları önerilmektedir. Ayrıca, yüzeysel kirleticilerin etkisinin görüldüğü kireçtaş1 akiferlerinde yeraltı suyu kalitesini koruyabilmek için bu litolojik birimler üzerinde tarımsal faaliyetlerde daha az kimyasal ve hayvansal gübre kullanılmalı, hayvansal gübreler geçirimsiz seviyeler (geçirimsiz beton yüzeyler ya da geçirimsiz kalın muşambalar üzerinde) oluşturularak depolanmalıdır.

\section{Teşekkür / Katkı Belirtme \\ Acknowledgement}

$\mathrm{Bu}$ çalışma TÜBİTAK tarafindan 114Y091 nolu proje ile maddi olarak desteklenmiştir. Yazarlar makalenin inceleme ve değerlendirme aşamasında yapmış oldukları katkılardan dolayı editör ve hakem/hakemlere teşekkür ederler.

\section{Yazar katkısı}

Author contribution

$\mathrm{Bu}$ makalenin yazarları çalışmanın planlanması, araziden su ve kayaç örneklerinin toplanması ve sonuçların yorumlanmasına birlikte katk1 sağlamışlardır.

\section{Etik beyanı \\ Declaration of ethical code}

Bu makalenin yazarları, bu çalışmada kullanılan materyal ve yöntemlerin etik kurul izni ve / veya yasal-özel izin gerektirmediğini beyan etmektedir.

\section{Çıkar çatışması beyanı \\ Conflicts of interest}

Yazarlar herhangi bir çıkar çatışması olmadığını beyan eder.

\section{Kaynaklar \\ References}

Abdelshafy, M., Saber, M., Abdelhaleem, A., Abdelrazek, S.M. \& Seleem, M. (2019). Hydrogeochemical processes and evaluation of groundwater aquifer at Sohag city, Egypt. Scientific African, 6, e00196. https://doi.org/10.1016/j.sciaf.2019.e00196.

Akbaş, B., Akdeniz, N., Aksay, A., Altun, İ.E., Balcı, V., Bilginer, E., Bilgiç, T., Duru, M., Ercan, T., Gedik, İ., Günay, Y., Güven, İ.H., Hakyemez, H.Y., Konak, N., Papak, İ., Pehlivan, Ș., Sevin, M., Şenel, M., Tarhan, N., Turhan, N., Türkecan, A., Ulu, Ü., Uğuz, M.F. \& Yurtsever, A. (2011). 1:1.250.000 ölçekli Türkiye Jeoloji Haritası. Maden Tetkik ve Arama Genel Müdürlüğ̈ Yayını, Ankara-Türkiye.

Aksever, F. (2019). Hydrogeochemical characterization and water quality assessment of springs in the Emirdağ (Afyonkarahisar) basin, Turkey. Arabian Journal of Geosciences.12:780. https://doi.org/10.1007/s12517-019-4942-7.

Clark, I. (2015). Groundwater Geochemistry and Isotopes, CRC Press, Taylor and Francis Group, Boca Raton, London, New York. 
Çapar, G. (2019). Su Kaynakları Yönetimi ve İklim Değişikliği. İklim Değişikliği Alanında Ortak Çabaların Desteklenmesi Projesi (iklimiN), T.C. Çevre ve Şehircilik Bakanlığı Çevre Yönetimi Genel Müdürlüğü, Ankara.

Çetindağ, B. (2002). Dipsiz Göl (Elâzı̆̆) kaynağının hidrojeoloji incelemesi. Firat Üniversitesi Fen ve Mühendislik Dergisi, 14(1), 169-180.

Davraz, A. \& Batur, B. (2021). Hydrogeochemistry characteristics of groundwater and health risk assessment in Yalvaç-Gelendost Basin (Turkey). Applied Water Science, 11: 67. https://doi.org/10.1007/s13201-021-01401-9.

Göçmez, G., Kara, İ. \& Ayaz Bozdağ, A. (2007). Rize ilindeki sicak ve mineralli suların hidrokimyasal özellikleri. Selçuk.Üniversitesi Mühendislik.Mimarlı Fakültesi Dergisi, 23(1-2), 165-175.

Güler, C., Thyne, G.D., Tağa, H. A\& Yıldırım, Ü. (2017). Processes governing alkaline groundwater chemistry within a fractured rock (ophiolitic melange) aquifer underlying a seasonally inhabited headwater area in the Aladağlar range, (Adana, Turkey). Geofluids, 3153924:

https://doi.org/10.1155/2017/3153924.

Han, D., Song, X. \& Currell, M.J. (2016). Identification of antropogenic and natural inputs of sulfate into a karstic coastal groundwater system in northeast China: evidence from major ions, $\delta^{13} \mathrm{C}_{\mathrm{DIC}}$ and $\delta^{34} \mathrm{~S}_{\mathrm{SO}}$. Hydrology and Earth System Sciences, 20, 1983-1999. https://doi.org/10.5194/hess-201983-2016.

Heerdink, R. \& Griffioen, J. (2008). Methodeontwikkeling voor het berekenen van het gehalte reactief ijzer uit totaalgehaltes ijzer en aluminium in sediment. Directie TNO Geological Survey of the Netherlands, Deltares TNO-rapport.

Hem, J.D. (1989). Study and Interpretation of the Chemical Characteristics of Natural Water. Third edition. US Geological Survey WaterSupply Paper 2254, Washington, United States Government Printing Office, 263p.

Hussien, B.M. \& Faiyad, A.S. (2016). Modeling the hydrogeochemical processes and source of ions in the groundwater of aquifers within KasraNukhaib Region (West Iraq). International Journal of Geosciences, 7, 1156-1181. https://doi.org/ 10.4236/ijg.2016.710087.

Kebede, S., Travi, Y., Alemayehu, T. \& Ayenew, T. (2005). Groundwater recharge, circulation and geochemical evolution in the source region of the Blue Nile river, Ethiopia. Applied Geochemistry, 20, 1658-1676. https://doi.org/ 10.1016/j.apgeochem.2005.04.016.
Kim, H. \& Park, S. (2016). Hydrogeochemical characteristics of groundwater highly polluted with nitrate in an agricultural area of Hongseong, Korea. Water, $8, \quad 345$. https://doi.org/10.3390/w8080345.

Kimball, B.A. (1981). Geochemistry of spring water, Southeastern Uinta Basin, Utah and Colorado (Geological survey water-supply paper 2074). U.S. Government printing office, Washington.

Kipman, E. (1981). Keban'1n Jeolojisi ve Keban Şaryaj1, Ístanbul Üniversitesi Yerbilimleri Dergisi, 1-1,2 75-81.

Kürüm, S., Akgül, B. \& Erdem, E. (1999). Eski ArapgirŞıhlar (Malatya-Elâzığ) Köyleri çevresindeki volkanitlerin petrografik ve petrolojik özellikleri. Geosound/ Yerbilimleri 34, 187-201.

Majkić-Dursun, B., Petković, A. \& Dimkić, M. (2015). The effect of iron oxidation in the groundwater of the alluvium aquifer of the Velika Morava River, Serbia, on the clogging of water supply wells. Journal of the Serbian Chemical Society, $80 \quad$ (7), 947-957. https://doi.org/10.2298/JSC140204089M.

Milanovic, P.T. (1981). Karst Hydrogeology. Water resources publications, P.O. Box 2841, Littleton, Colorado, Amerika Birleşik Devletleri.

Olivier, N. (2012). Characterization of the spatial distribution of iron-and manganese oxides in the Sterksel Formation at the Maalbeek quarry, The Netherlands. Faculty of Geosciences, Utrecht University, Master's Thesis, 80 p., Netherlands.

Öztekin Okan Ö. \& Güven A. (2019). Hydrochemistry of groundwaters from alluvial and fractured igneous aquifers at the western region of Lake Hazar (Elâzı ğ, Turkey). Arabian Journal of Geosciences, 12: 52. https://doi.org/ 10.1007/s12517-018-4209-8.

Öztekin Okan Ö., Güven A. \& Çetindağ B. (2018). Plajköy Kaynağı'nın hidrojeoloji incelemesi. Maden Tetkik Arama Dergisi, 156, 234-235. https://doi.org/10.19111/bulletinofmre.376767.

Öztekin Okan, Ö. \& Çetindağ, B. (2005). Hydrogeochemical and isotopic investigation of the Kolan geothermal field, southeastern Turkey. Environmental Geology, 48,179-188. https://doi.org/ 10.1007/s00254-005-1286-2.

Öztekin Okan, Ö., Kalender, L., Çetindağ, B. (2018). Trace-element hydrogeochemistry of thermal waters of Karakoçan (Elâzı̆̆) and Mazgirt (Tunceli), Eastern Anatolia, Turkey. Journal of Geochemical Exploration, 194, 29-43. https://doi.org/ 10.1016/j.gexplo.2018.07.006. 
Perez-Ceballos, R., Canul- Macario, C., PachecoCastro, R., Pacheco- Avila, J., Euan- Avila, J. \& Merino- Ibarra, M. (2021). Regional hydrogeochemical evolution of groundwater in the Ring of Cenotes, Yucatán (Mexico): An inverse modelling approach. Water, 13, 614. https://doi.org/10.3390/w13050614.

Salem, Z.E. \& El-Bayumy, D.A. (2016). Hydrogeological, petrophysical and hydrogeochemical characteristics of the groundwater aquifers east of Wadi El-Natrun, Egypt. National Research Institute of Astronomy and Geophysics, 5, 124- 146. https://doi.org/10.1016/j.nrjag.2015.12.001.

Semiz Ü., Gücer, M.A. \& Alemdağ S. (2021). Şiran (Gümüşhane) ilçe merkezi su kaynaklarının kalitesi ve hidrojeokimyasal özelliklerinin değerlendirilmesi. Doğal Afetler ve Çevre Dergisi, 7(1), 59-74. https://doi.org/10.21324/dacd.804464.

Sipahi F. \& Uslu S. (2016). Investigation of the quality and physical-geochemical characteristics of the drinking water in Gümüşhane (Turkey) city central. Arabian Journal of Geosciences, 9, 600. https://doi.org/ 10.1007/s12517-016-2620-6.

Şahinci, A. (1991). Doğal Suların Jeokimyası. Reform Matbaası, İzmir, 548s.

Şener, Ş. \& Güneş, D. (2015). Aksu (Isparta) Ovası yüzey ve yeraltı sularının hidrojeokimyasal özellikleri ve su kalitesi. Pamukkale Üniversitesi Mühendislik Bilimleri Dergisi, 21(6), 260-269. https://doi.org/10.5505/pajes.2014.85547.
Tahmasebzadeh Bastam, E. ve Gültekin, F. (2017). Değirmendere (Trabzon) havzası kaynak sularında su-kayaç etkileşimi. Jeoloji Mühendisliği Dergisi / Journal of Geological Engineering, $41 \quad$ (1), 59-78. https://doi.org/10.24232/jmd.314585.

T.C. Tarım ve Orman Bakanlığı (2016). İklim Değişikliğinin Su Kaynaklarına Etkisi Projesi. Yönetici Özeti.

TSE (2005). TS266, Türk İçme Suyu Standartları. Türk Standartları Enstitüsü, Ankara

Türkmen, İ. \& Aksoy, E. (1998). Arapgir (Malatya), Çemişgezek (Tunceli), Elâzı ̆̆ dolaylarındaki Neojen birimlerinin stratigrafik-sedimantolojik incelenmesi ve bölgesel korelasyonu. Türkiye Petrol Jeologlarl Derneği/TPJD Bülteni, 10 (1), 15-33.

WHO (2011). World Health Organization, 2011. Guidelines for drinking-water quality. Vol. 1.

Yuan, J., Xu, F., Deng, G., Tang, Y. \& Li, P. (2017). Hydrogeochemistry of shallow groundwater in a karst aquifer system of Bijie City, Guizhou Province. Water, 9, 625. https://doi.org/10.3390/w9080625.

Yüksel, A. (2007). Üçtepe yöresinin (İmamoğlu Adana) hidrojeolojik incelemesi. Çukurova Üniversitesi Fen Bilimleri Enstitüsü, Yüksek Lisans Tezi, Adana. 